\title{
The Impact of Ownership Structure and Capital Structure on Financial Performance of Vietnamese Firms
}

\author{
Do Xuan Quang ${ }^{1,2} \&$ Wu Zhong Xin ${ }^{2}$ \\ ${ }^{1}$ Academy of Journalism and Communication, Vietnam \\ ${ }^{2}$ Business School, Hunan University, Hunan, China \\ Correspondence: Do Xuan Quang, Academy of Journalism and Communication, 36 Xuan Thuy, Caugiay, Hanoi, \\ Vietnam. Tel: 00-84-982242594. E-mail: quangbaochi@gmail.com
}

Received: November 18, 2013

Accepted: December 17, 2013

Online Published: January 23, 2014

doi: 10.5539/ibr.v7n2p64

URL: http://dx.doi.org/10.5539/ibr.v7n2p64

\begin{abstract}
This article studies the impact of ownership structure and capital structure on firms' financial performance in context of an emerging transitional economy. According to research findings, capital structure has a negative impact with statistical significance on financial performance (measured by ROA, ROE). The higher level of state ownership in ownership structure of a firm is, the better financial performance it has. While clear evidences with statistical significance of the impact of managerial ownership on financial performance have not been found, this study found out that, the level of entrenchment of managers in state-owned enterprises (SOEs) is higher than that of businesses of other types.
\end{abstract}

Keywords: ownership structure, capital structure, financial performance, entrenchment, Vietnam

\section{Introduction}

It is not easy to explain issue of financial leverage decisions in capital structure in a short article. Theoretical and empirical studies so far explain, to some extend, certain aspects of the capital structure of an organization. From the thematic research of Modigliani and Miller (1958), there have been so far many theories explaining capital structure selection of a firm. Typical theories with strong impact and persuasive explanation for the issue such as: trade-off theory, pecking-order theory and the issue of information asymmetry, agency cost theory. The trade-off theory states that there exists an optimal capital structure for a firm by arguing that a firm, with maximum values, will find an optimal capital structure by trade-off interests (Miller, 1977). It means that, at the firm's maximum value, the marginal cost of debt is equal to the marginal benefit of debt financing. In contrast, the pecking-order theory developed by Myers and Majluf (1984), Myers (1984) argues that there is no optimal capital structure for a firm, and the firm uses debts once internal capital sources (retained earnings for example) are used up as the top priority, followed by debts and then equities in case they are needed to finance the firm's operations. Besides, the agency cost theory given by Jensen and Meckling (1976) and further developed by Jensen (1986) suggests that the optimal capital structure of a firm can exist and be identified by minimizing agency costs between stakeholders: shareholders and managers, shareholders and debt holders.

Previous studies try to find a clear explanation for capital structure selection and its impact on values and financial performance of a firm. In another angle, some studies investigate the impact of ownership structure on the performance and values of a firm. These studies attempt to give empirical evidences to explain existing financial theories. However, empirical studies give mixed or contradictory evidences regardless of data derived from developed countries or developing countries or transitional economies. Studies of relation between capital structure and financial performance may include studies of Fama and French (2002), Abor (2005), Berger and Banoccorsi di Pitti (2006), Zuitun and Tian (2007), Ebaid (2009), Margaritis and Psillki (2009). Relation between ownership structure and financial performance of firms are stated in studies by Han and Suk (1998), McConnell and Servaes (1990), Morck et al. (1988), Margaritis and Psillki (2009).

In our understanding, research materials of capital structure and its impact on values and performance of firms mainly from developed economies like U.S. and Europe. There have not been many researches in the context of emerging economies, especially in the context of Vietnam, a transitional emerging economy with numerous outstanding achievements after more than 25 years of opening up and renovation. Objective of this study is to 
examine the concurrent impacts of ownership structure and capital structure on financial performance of Vietnamese firms. Multivariate regression model is used to test the cross-panel data of firms listed on Ho Chi Minh Stock Exchange (HoSE) in the period of 2009-2012. A firm's performance is represented by Return on Assets ratio (ROA) and Return on Equity ratio (ROE), while the capital structure is represented by total debt/asset ratio (TDA), long-term debt/total asset (LDA), short-term debt/total asset (SDA); and ownership structure is represented by managerial and state ownership in the model.

The rest of the article is organized as follows: Section 2 presents a literature review of the capital structure and corporate performance, ownership structure and corporate performance. Section 3 introduces methodology and measurement of variables. Section 4 presents research results and discussion, and finally conclusions are presented in Section 5.

\section{Literature Review}

\subsection{Ownership Structure and Financial Performance}

According to Jensen and Meckling (1976), managers may not always act for the interests of those who hire them, but possibly because of their own sake in distributing benefits to stakeholders. This will increase agency problem between managers and shareholders, between shareholders and debt-holders, between inside shareholders and outside investors. Therefore, if managerial ownership is increased, their interests will be balanced to the interests of shareholders leading to possible remarkable reduction of conflicts between managers and shareholders, gradual solution to agency problem and as a result, improvement of firms' financial performance. Morck et al. (1988), when examining the relationship between Tobin's Q rate and internal ownership level, points out that within a certain extend of internal ownership level, the Tobin's Q rate is correlated positively with internal ownership, while negatively in other ranges. This indicates a non-linear relationship between internal ownership and firms' financial performance (measured by Tobin's Q). It also shows that a firm may achieve the best performance when choosing ownership structure at a specific ratio.

In addition, Fama and Jensen (1983) prove that the increase of managerial ownership would lead to the increase of entrenchment of managers. This means that the increase of the shared managerial ownership will bring about the increase managers' influence on business performance and the decrease of investors' influence on financial performance. McConnell and Servaes (1990) discover that the entrenchment of managers will be affected if institutional ownership is increased. Like Morck et al. (1988), they indicate that business performance (representing Tonbin's Q) is in a non-linear relationship with internal ownership, but a positive linear relationship with institutional ownership. Han and Suk (1998) discover that increased internal ownership leads increased business performance (measured by stock returns). However, excessive internal ownership will cause damage to business productivity. They also show a positive relationship between institutional ownership and business performance (stock returns), which proves that institutional ownership has a negative impact on the entrenchment of managers. A recent study by Margaritis and Psillaki (2009) point out that impact of ownership concentration's agency costs is different among different sectors. However, they conclude that in general, concentrated ownership is positively associated with debt level in capital structure. In summary, all the above mentioned researches show the same result of a positive correlation between the increase in managerial ownership and the increase of business performance and vice versa. Most of those researches state that excessive managerial ownership would cause damage to the financial performance of firms, and managerial ownership should be remained at a proper level for businesses.

\subsection{Capital Structure and Financial Performance}

Viewed from a negative-positive relationship, Ebaid (2009) summarize from previous theoretical and empirical researches and state that the selection of capital structure of a firm is influenced by many factors, and a financial theory with it unique assumptions can not give comprehensive explanations for the capital structure selection. Therefore, it is easy to understand that financial theories offer different perspectives on the relationship between capital structure and financial performance of firm. Empirical evidences also divide results by the different directions to support various theoretical predictions. First, according to trade-off theory, there exists a positive relationship between capital structure selection and financial performance (which is profitability measured by ROA, ROE). Firms with higher profitability tend to have higher debt to benefit from the tax shield (Miller, 1977). Supporting this argument, Jensen (1986) takes the view that debt level in increased capital structure may have positive effects on financial performance of a firm by reducing agency problem between shareholders and managers. Relating to benefit trade-offs between managers and shareholders, Harris and Raviv (1991) suggest that the firm can increase debt in capital structure to reduce agency cost between managers and shareholders, which is considered appropriate. Empirical researches support this school of thought are Abor (2005), Berger and 
Bonaccoris di Pitti (2006), Margaritis and Pasillaki (2009) and others.

Contrary to the above mentioned viewpoint that capital structure negatively relates to firm's financial performance, Myers (1984) points out the existence of information asymmetry problem between insiders (managers) and outside investors on the fact that business pricing relating to the issuance of new shares-a transferring step from old to new shareholders - may be harmful to the existing shareholders (see Myers \& Majluf, 1984). To avoid that negative impact, managers will prioritize using endogenous sources (such as retained earnings), then debts and finally equities issued. Accordingly, the higher firms' profitability is, the more they tend to prioritize using endogenous funds than debts compared with firms with lower profitability. With this, it can be concluded that debt level in the capital structure of a firm is inversely related to financial performance (i.e. profitability). In another study, Ross (1977) states that share capital is less favored by investors because they think that managers will take advantage of the issuance of new shares to make higher pricing of the firms. As a result, investors believe that it is a good sign to decide to use internal funds instead of issuing equities. Empirical evidences of a negative relationship between capital structure and financial performance can be found in Titman and Wessels (1988), Rajan and Zingales (1995), Wiwattanakantang (1999), Gleason et al. (2000), Fama and French (2002), and Zeitun and Tian (2007). Besides, a number of empirical studies provides mixed and contradict results among measured variables of capital structure and those of firm's financial performance with representative meaning (e.g., Ebaid, 2009; Nguyen \& Ramachandran, 2006).

\section{Research Methodology and Measurement of Variables}

\subsection{Research Methodology}

This study uses data base from financial statements of listed companies on Ho Chi Minh Stock Exchange (HoSE) trading on 31/05/2013 for the period of 2009-2012. Due to different characteristics, financial institutions (banks, insurance companies, securities firms and other financial institutions) are excluded from the samples. Together with the screening of financial data availability for sampled companies for survey period (2009-2012), finally, sample of 134 non-financial companies was selected.

Multivariate regression model was used to test the impact of ownership structure, capital structure on firms' financial performance under the following form:

$$
\mathrm{PERF}_{\mathrm{it}}=\beta_{0}+\beta_{1} \mathrm{LEV}_{\mathrm{it}}+\beta_{2} \mathrm{MaOW}_{\mathrm{it}}+\beta_{3} \mathrm{STATE}_{\mathrm{it}}+\beta_{4} \mathrm{GROW}_{\mathrm{it}}+\beta_{5} \mathrm{TANG}_{\mathrm{it}}+\beta_{6} \mathrm{FSIZE}_{\mathrm{it}}+\mathrm{u}_{\mathrm{it}}
$$

with $\mathrm{i}=1,2, \ldots, 134$ and $\mathrm{t}=1,2,3,4$

In which

PERF: Firm's Financial Profitability (ROA, ROE)

LEV: Financial Leverage (TDA, LDA, SDA)

MaOW: Managerial Ownership

STATE: State Ownership

GROW: Growth Opportunity

TANG: Tangibility

SIZE: Firm Size

$\mathrm{u}_{\mathrm{it}}=\mu_{\mathrm{it}}+\varepsilon_{\mathrm{it}}$ with $\varepsilon$ : random error with $\mathrm{E}\left(\varepsilon_{\mathrm{it}}\right)=0$ and $\operatorname{Var}\left(\varepsilon_{\mathrm{it}}\right)=\delta^{2}$ : random error and $\mu$ is the panel-data error; $\beta_{0}$ : constant value; $\beta_{1}, \ldots, 6$ : estimated coefficients of explanatory variables.

\subsection{Measurement of Variables}

(1) Financial performance, measured based on book values calculated from financial statements represented by Return on Assets ratio (ROA) and Return on Equity ratio (ROE) (Abor, 2005; Ebaid, 2009).

(2) Capital Structure, like Abor (2005), Ebaid (2009), measured by financial leverages represented by Total Debt on Total assets ratio (TDA), Long-term Debt on Total Assets ratio (LDA) and Short-term Debt on Total Assets (SDA).

(3) Managerial ownership, measured by the rate of shares hold by members of Board of Directors (see Han \& Suk, 1998; Wiwanttanakantang, 1999).

(4) State ownership, a binary variable, has value of 1 if a firm has the rate of state ownership of $51 \%$ and above (under Vietnamese Enterprise Law 2005) and reversely if the value is 0 (Nguyen \& Ramachandran, 2006).

(5) Growth opportunity, measured by the percentage of change in total assets (Nguyen \& Ramachandran, 2006). 
(6) Firm size, measured by the logarithm of total assets (Abor, 2005) (unit 10 billions Vietnamese Dong).

(7) Tangibility, calculated by Tangible Assets on Total Assets ratio (Wiwattanakantang, 1999).

Unlike many studies in different economies in the world, data of before tax profit is used instead of before tax and interests profit, because interest expense is not clearly presented in corporate financial statements in Vietnam.

\section{Results and Discussions}

Table 1. Descriptive statistics

\begin{tabular}{lccccccccc}
\hline & ROA & ROE & TDA & LDA & SDA & MaOW & TANG & GROW & SIZE \\
\hline Total Sample & & & & & & & & & \\
Minimum & -0.6473 & -1.8722 & 0.0648 & 0.0000 & 0.0256 & 0.0187 & 0.0012 & -0.6742 & 1.0977 \\
Maximum & 0.6089 & 3.4119 & 1.0639 & 1.0639 & 0.9504 & 0.8703 & 0.9275 & 4.2976 & 3.7468 \\
Mean & 0.0833 & 0.1596 & 0.4876 & 0.1332 & 0.3544 & 0.4178 & 0.2432 & 0.1621 & 2.0059 \\
Std.Dev & 0.0954 & 0.2703 & 0.2177 & 0.1721 & 0.1941 & 0.2017 & 0.2237 & 0.3197 & 0.5196 \\
SOEs & & & & & & & & & \\
Minimum & -0.0216 & -0.0898 & 0.0942 & 0.0000 & 0.0268 & 0.3637 & 0.0238 & -0.2244 & 1.1326 \\
Maximum & 0.3861 & 0.5975 & 0.8701 & 0.6545 & 0.7031 & 0.8703 & 0.9275 & 1.1340 & 3.1243 \\
Mean & 0.0996 & 0.1711 & 0.4856 & 0.1814 & 0.3042 & 0.5860 & 0.3100 & 0.1275 & 2.0252 \\
Std.Dev & 0.0891 & 0.1151 & 0.2348 & 0.2037 & 0.1810 & 0.0889 & 0.2651 & 0.2049 & 0.4836 \\
\hline
\end{tabular}

Table 1 presents a summary of statistic description. It shows that, first, the mean value of ROA and ROE for total sample is $8.33 \%$ and $15.96 \%$, the figures for SOEs are $9.96 \%$ and $17.11 \%$ respectively. These indicators show that listed companies do not operate really efficiently during the study period (although level of efficiency in SOEs is slightly higher), yet, this is considered as normal in the context of Vietnam after global financial crisis and public debt in Europe. Vietnam stock market, after a period of "hot" growth, became "cooled down" to its actual status. The funding of companies trading on capital markets has greatly reduced under the impact of the global financial crisis in 2009. In addition, the fact that commercial banks have tightened their credits to businesses and aggressively recovered debts due has made many firms fall into capital shortage and financial distress. All, directly or indirectly, cause extremely negative impact on productivity (financial and business) of the firms (ROA, ROE ratios of some firms even remain negative)

Second, the mean value of total debt on total assets ratio (TDA), long-term debt on total assets ratio (LDA) and short-term debt on total assets (SDA) for the entire sample are $48.76 \%, 13.32 \%$ and $35.44 \%$ respectively. These figures for SOEs are $48.56 \%, 18.14 \%$ and $30.42 \%$ respectively; in comparison with firms in general, TDA is almost the same, LDA is dramatically higher, SDA is dramatically lower. SOEs tend to use more long-term debts, however, short-term debts are still used, mainly for debt financing activities of Vietnam enterprises (accounting for $60-70 \%$ of total debts). It is a prominent feature in the debt structure of firms in other emerging or transitional markets. Firms who often use short-term debts (less than one year) to fund their investment activities, both short-term and long-term are considered as highly risky at debts due. Vietnamese commercial banks, due to many reasons including embryonic market and low level of financial security level, provide mainly short-term credits to the market. Thanks to longtime relationship with banking partners, SOEs may enjoy more long-term favorable bank loans which results in higher ratio of long-term debt in the capital structure in compare with firms of other types. The mean value of TDA also presents a balance between debts in firms' capital structure and other forms of capital raising (equities, internal equities). This is appropriate in Vietnamese context, when the stock market is becoming a more effective fund-raising channel, although the effectiveness is not yet high for listed firm and the corporate bond market is gradually shaped.

Third, the average managerial ownership rate is $41.78 \%$ (that of SOEs is $58.60 \%$ ), proves high level of concentration of ownership in Vietnamese listed firms. Especially in SOEs, when the state ownership is represented by some members of Board of Directors. However, highly concentrated management ownership means high level of debts and managerial entrenchment. This on one hand creates a high level of concentration in management and more effective administration when the interests of managers more closely associated with 
the interests of shareholders; on the other hand reduces the ability to attract investment from outside investors because of managerial entrenchment and conservativeness. Furthermore, for SOEs or enterprises with dominant state-owned shares, if there is no effective controlling and supervising mechanism, there will be unexpected consequences such as limited productivity, possible financial distress or payment inability; decreased state ownership along with unethical behaviors of management; unemployment rate along with payment inability, insolvency or bankruptcy.

Table 2. Effect of variables on ROA

\begin{tabular}{|c|c|c|c|c|c|c|}
\hline & \multicolumn{3}{|c|}{ ROA of total sample } & \multicolumn{3}{|c|}{ ROA of SOEs } \\
\hline & TDA & LDA & SDA & TDA & LDA & SDA \\
\hline TDA & $-0.253 * * *$ & & & $-0.310 * * *$ & & \\
\hline LDA & & $-0.238 * * *$ & & & $-0.314 * * *$ & \\
\hline SDA & & & $-0.196 * * *$ & & & $-0.267 * * *$ \\
\hline MaOW & 0.014 & 0.017 & 0.025 & -0.043 & $0.269 * * *$ & -0.044 \\
\hline TANG & $-0.041 * *$ & 0.014 & $-0.107 * * *$ & $-0.040^{*}$ & 0.051 & $-0.151 * * *$ \\
\hline GROW & $0.052 * * *$ & $0.054 * * *$ & $0.044 * * *$ & $0.104 * * *$ & $0.077 * *$ & $0.092 * *$ \\
\hline SIZE & $0.019 * *$ & $0.021 * *$ & -0.011 & $0.035^{* * *}$ & $0.039 * *$ & -0.011 \\
\hline STATE & $0.021 * *$ & $0.033 * * *$ & 0.009 & & & \\
\hline $\mathrm{R}^{2}$ & 0.313 & 0.140 & 0.481 & 0.679 & 0.440 & 0.381 \\
\hline $\mathrm{F}$ & 39.267 & 14.008 & 19.069 & 41.833 & 14.537 & 12.204 \\
\hline Sig. & 0.000 & 0.000 & 0.000 & 0.000 & 0.000 & 0.000 \\
\hline
\end{tabular}

$* * *, * *, *$ level of statistical significance is equal to $1 \%, 5 \%$ and $10 \%$, respectively.

Table 2 presents results of multiple regression analysis of factors affecting financial performance (ROA) which is described in section 3.2. As a result, measurements of capital structure (TDA, LDA and SDA) are all significantly negatively correlated with ROA (confidence level of 99\%) in both cases of firms in general and SOEs in particular. This evidence supports pecking order theory within the context of Vietnamese firms, in accordance with the practice that debts are used as priority, then comes equities. However, the more debts, the less financial performance ROA. Although debts can reduce agency problem between managers and investors and increase property generation; yet, high debts mean high risk of payment capacity loss. On the other hand, firms with high profitability often use a large part of retained earnings for reinvestment and a small part of that for dividends paid to shareholders and other funds. This also contributes to creating a negative relationship between capital structure and ROA. Meanwhile, managerial ownership (MaOW) has a positive relationship without statistical significance with ROA for firms in general. State ownership (STATE) is significantly positively correlated with ROA, yet there has not significantly statistical evidence for SDA model. This shows that SOEs have higher ROA than firms of other types. In other words, the higher level of state ownership in firms, the higher ROA.

Traditional factors affecting capital structure such as Tangibility, Growth opportunity, Firm size provide evidences of their impacts to firms' financial performance (ROA). Tangibility (TANG) is in a significantly negative relationship with ROA for TDA and SDA models in both cases (total sample and SOEs), yet there has been any statistical evidence of a positive relation between TANG and ROA for LDA model. This reflects an objective fact of a long-term debt environment in Vietnam which is not preferred. Debts (bank credits) are mostly short-term.

Firms with high tangibility have low financial performance (ROA). Therefore, firms should have appropriate structure of tangible assets over total assets. Growth Opportunities (GROW) is significantly positively correlated with ROA in all 3 models TDA, LDA, SDA for both cases (total samples and SOEs). In economic sense, this evidence is appropriate, both theoretically and practically, as firms with high growth opportunities also have high financial performance. Firm size (SIZE) is positively correlated with ROA (confidence level 99\%) in both TDA and LDA models for both cases (total samples and SOEs). However, there has not been statistically significant results of a negative relation between firm size and ROA for SDA model. The study shows that the bigger the 
firm size of firms with long-term debt is, the higher financial performance (ROA) they have; and it tends to be easier for firms with large size to access long-term debts.

Table 3. Effect of variables on ROE

\begin{tabular}{|c|c|c|c|c|c|c|}
\hline & \multicolumn{3}{|c|}{ ROE of total sample } & \multicolumn{3}{|c|}{ ROE of SOEs } \\
\hline & TDA & LDA & SDA & TDA & LDA & SDA \\
\hline TDA & $-0.215^{* * *}$ & & & $-0.239 * * *$ & & \\
\hline LDA & & $-0.336 * * *$ & & & $-0.251 * * *$ & \\
\hline SDA & & & $-0.160 * * *$ & & & $-0.196 * * *$ \\
\hline $\mathrm{MaOW}$ & -0.017 & -0.019 & -0.006 & $-0.234 *$ & 0.008 & -0.225 \\
\hline TANG & $-0.158 * * *$ & -0.069 & $-0.200 * * *$ & $-0.119 * * *$ & -0.045 & $-0.202 * * *$ \\
\hline GROW & $0.113 * * *$ & $0.119 * * *$ & $0.107 * * *$ & $0.167 * * *$ & $0.146^{*}$ & $0.157 * * *$ \\
\hline SIZE & $0.043^{* *}$ & $0.060 * * *$ & 0.018 & 0.037 & 0.041 & 0.001 \\
\hline STATE & $0.055^{* *}$ & $0.072 * * *$ & $0.048^{*}$ & & & \\
\hline $\mathrm{R}^{2}$ & 0.134 & 0.131 & 0.095 & 0.362 & 0.285 & 0.251 \\
\hline $\mathrm{F}$ & 13.337 & 12.960 & 9.065 & 11.234 & 7.897 & 6.629 \\
\hline Sig. & 0.000 & 0.000 & 0.000 & 0.000 & 0.000 & 0.000 \\
\hline
\end{tabular}

***, **, * level of statistical significance is equal to $1 \%, 5 \%$ and $10 \%$, respectively.

Table 3 shows results of regression analysis between studied variables and financial performance (ROE). Measurements of capital structure (such as TDA, LDA, SDA) are inversely correlated with statistical significance with ROE for both cases (total samples and SOEs). Firms with higher debt level will have lower profits, because high debt will contribute to increase possibilities of financial exhaustion and bankruptcy of firms. High debt means high agency costs of debt and increased financial exhaustion expenses. Statistically significant evidences of a negative relationship between managerial ownership (MaOW) and ROE in this study have not been found. Particularly for case of SOEs with TDA model, MaOW is in a significantly negative relationship with ROE. This result indicates that the level of managerial entrenchment in SOEs is higher than that in enterprises of other types. The managerial entrenchment will increase the conservativeness and the lack of flexibility for firms, and at the same time cause hesitation of investors when making decisions to invest in firms with high level of managerial entrenchment. State ownership (STATE) has a significantly positive relationship with ROE, the level of impact is not yet high which means that firms with high level of state ownership will have high Return on Equity ratio. This reflects Vietnamese context in which firms with state ownership still receive protection and incentives from the government, especially SOEs.

Like the case of ROA, Table 3 also shows Tangibility, Growth opportunities, Firm size significantly affect financial performance which is measured by ROE. Specifically, Tangibility is negatively correlated with ROE in both cases, total samples and SOEs for all three models TDA, LDA and SDA, though, for the case the LDA model, it is not statistically significant. This shows that firms with more mobile assets will have higher financial performance. The fact that Growth opportunities significantly correlated with ROE implies high profitability for firms with high growth opportunities. Firm size is positively associated with ROE in the case of total samples, significant evidences not yet found in the case of SOEs. Regression results show that firms with long-term debt, if have large size, will have high financial performance. However, this is less common in the context of Vietnam, while short-term debt is still a popular form of debt financing (accounting for $60-70 \%$ of total debt).

\section{Conclusions}

By using a set of 134 samples of non-financial firms listed on HoSE in the period 2009-2012 for studying and analyzing the impact of ownership structure, capital structure on firms' financial performance through multiple regression analysis method for all three models measuring financial leverages TDA, LDA and SDA. Findings of the study show that capital structure is significantly inversely correlated with firms' financial performance (as measured ROA, ROE). While the ownership structure, represented by managerial ownership, has unclear impact without statistical significance on firms' financial performance (ROA, ROE) for all firms in general, while for SOEs, there is a significant negative relation between managerial ownership and financial performance measured 
by ROE. This shows that the level of entrenchment of managers in SOEs is higher than that in enterprises of other types. Especially, in the context of Vietnam, state ownership has a positive impact on firms' financial performance (ROA, ROE). A firm with high level of state ownership in its ownership structure will have high financial performance.

Like many other previous international studies in developed and emerging economies, this study also found evidences of the influence of firm factors on capital structure financial performance such as Tangibility, Growth opportunities and Firm size. Evidence of a negative relationship between capital structure and financial performance supports pecking order theory which shows that Vietnamese firms will prioritize using internal funds first, then debs and finally equities if needed.

\section{References}

Abor, J. (2005). The effect of capital structure on profitability: an empirical analysis of listed firms in Ghana. Journal of Risk Finance, 6, 438-447. http://dx.doi.org/10.1108/15265940510633505

Berger, A., \& Bonaccorsi di Patti, E. (2006). Capital structure and firm performance: a new approach to testing agency theory and an application to the banking industry. Journal of Banking and Finance, 30(4), 1065-1102. http://dx.doi.org/10.1016/j.jbankfin.2005.05.015

Fama, E. F., \& French, K. R. (2002). Testing trade off and pecking order predictions about dividends and debt. Review of Financial Studies, 15, 1-33. http://dx.doi.org/10.2139/ssrn.199431

Fama, E. F., \& Jensen, M. (1983). Agency problem and residual claims. Journal of Law and Economics, 26, 327-349. http://dx.doi.org/10.2139/ssrn.94032

Gleason, K., Mathur, L., \& Mathur, I. (2000). The interrelationship between culture, capital structure, and performance: evidence from European retailers. Journal of Business Research, 50, 185-191. http://dx.doi.org/10.1016/S0148-2963(99)00031-4

Han, K. C., \& Suk, D. Y. (1998). The effect of ownership structure on firm performance: Additional evidence. Review of Financial Economics, 7(2), 143-155. http://dx.doi.org/10.1016/S1058-3300(99)80150-5

Harris, M., \& Raviv, A. (1991). The theory of capital structure. Journal of Finance, 46, 297-355. http://dx.doi.org/10.1111/j.1540-6261.1991.tb03753.x

Ebaid, I. E. (2009). The impact of capital-structure choice on firm performance: Empirical evidence from Egypt. Journal of Risk Finance, 10(5), 477-487. http://dx.doi.org/10.1108/15265940911001385

Jensen, M. (1986). Agency costs of free cash flow, corporate finance, and takeovers. American Economic Review, 76, 323-339. http://dx.doi.org/10.2139/ssrn.99580

Jensen, M., \& Meckling, W. H. (1976). Theory of the firms: Managerial behavior, agency costs and ownership structure. Journal of Financial Economics, 3, 305-360. http://dx.doi.org/10.1016/0304-405X(76)90026-X

Margaritis, D., \& Psillaki, M. (2010). Capital structure, equity ownership and firm performance. Journal of Banking \& Finance, 34(3), 621-632. http://dx.doi.org/10.1016/j.jbankfin.2009.08.023

McConnell, J. J., \& Servaes, H. (1990). Additional evidence on equity ownership and corporate value. Journal of Financial Economics, 27, 595-612. http://dx.doi.org/10.1016/0304-405X(90)90069-C

Miller, M. H. (1977). Debt and taxes. Journal of Finance, 32, 61-275. http://dx.doi.org/10.1111/j.1540-6261.1977.tb03267.x

Morck, R., Shleifer, A., \& Vishny, R. W. (1988). Management ownership and market valuation: An empirical analysis. Journal of Financial Economics, 20, 293-315. http://dx.doi.org/10.1016/0304-405X(88)90048-7

Myers, S. C. (1984). The capital structure puzzle. Journal of Finance, 34(3), 575-592. http://dx.doi.org/10.1111/j.1540-6261.1984.tb03646.x

Myers, S. C., \& Majluf, N. S. (1984). Corporate financing and investment decisions when firms have information that investors do not have. Journal of Financial Economics, 13, 187-221. http://dx.doi.org/10.1016/0304-405X(84)90023-0

Nguyen, T. D. K., \& Ramachandran, N. (2006). Capital structure in Small and Mediumsized Enterprises: The case of Vietnam. ASEAN Economic Bulletin, 23(2), 192-211. Retrieved from http://www.bupedu.com/lms/admin/uploded_article/eA.127.pdf

Rajan, G. R., \& Zingales, L. (1995). What do we know about capital structure? Some evidence from international data. Journal of Finance, 50, 1421-1460. http://dx.doi.org/10.1111/j.1540-6261.1995.tb05184.x 
Ross, S. A. (1977). The Determination of Financial Structure: the Incentive-Signaling Approach. Bell Journal of Economics, 8, 23-40. http://dx.doi.org/10.1016/0304-405X(92)90029-W

Titman, S., \& Wessels, R. (1988). The determinants of capital structure choice. Journal of Finance, 43, 1-19. http://dx.doi.org/10.1111/j.1540-6261.1988.tb02585.x

Zeitun, R., \& Tian, G. (2007). Capital structure and corporate performance: evidence from Jordan. Australasian Accounting Business and Finance Journal, 1, 40-53. Retrieved from http://ro.uow.edu.au/aabfj/vol1/iss4/3

Wiwattanakantang, Y. (1999). An empirical study on the determinants of the capital structure of Thai firms. Pacific-Basin Finance Journal, 7, 371-403. http://dx.doi.org/10.1016/S0927-538X(99)00007-4

\section{Copyrights}

Copyright for this article is retained by the author(s), with first publication rights granted to the journal.

This is an open-access article distributed under the terms and conditions of the Creative Commons Attribution license (http://creativecommons.org/licenses/by/3.0/). 